\title{
STRUCTURAL CHANGES AND STRUCTURAL TRANSFORMATION IN A MODERN DEVELOPMENT ECONOMY
}

\author{
Vladislav Marjanović \\ University of Niš, Faculty of Economic, Serbia \\ $\bowtie$ vladislav.marjanovic@eknfak.ni.ac.rs
}

UDC

330.342

Review paper

Received:

23.01.2015

Accepted:

27.03.2015

\begin{abstract}
The concepts of structure and structural changes can be applied in many different ways. Relatedly, the roughest distinction is reflected in two approaches: development economics approach and econometric approach. This paper will rely on the development economics, because it seems that the econometric approach oversimplifies the structural analysis and structural changes. Development economics, which evolved through the interaction between theoretical research and empirical studies, deals with many issues related to structure and growth in less developed (developing) countries. In development economics, the economic structure analysis is observed mostly through micro and macro approach. The paper relies on a macroeconomic approach which views the economic development as a set of interrelated long-term processes of structural transformation accompanying the growth.

Unlike the neoclassical approach, which makes a simple distinction of the economy to sectors producing tradable goods (with a high substitution) and sectors producing non-tradable goods, development economics studies structural adjustments of much serious complexity. Unlike other branches of economy, development economics has no universally accepted doctrine or paradigm. Instead, it is based on continuous evaluation of thinking, creating a ground for understanding the processes of modern economic development.
\end{abstract}

Keywords: economic structure, structural changes, structural transformation, development economy, sectors' proportions

\section{Introduction}

Economic development is a complex concept which, beside economic growth, also comprises: changes in economic structure, changes in social area, technology. Economic development is a process that implies the creation of new 
quality characteristics of an economy (along with the quantitative growth of the structure elements) and the exact dynamic character of economic structure provides a quality dimension of that process. Dynamics and changes in the economic structure do not refer only to the elements of the economic structure, but also to the very relationships among the elements. „The change of the relationship among the elements within an entity is called a structural change“ (Korosic, 1976, pg. 8).

The term "structural changes“ in the economy is most frequently used to explain the transformation in the composition of production, employment, demand and trade, which appears along with the development of a country (Doyle, 1997.). Both in developed and developing countries (industrialized and those in the process of industrialization), occur constant changes in the composition of input and output, propelled by technology and a desire to achieve greater competitive advantage.

There are many different uses of the concepts of structure and structural changes in the economy. In this paper, will be using an approach supported by development economics, because it seems that econometric approach, indisputably respectable and significant, oversimplifies the analysis of the structure and structural changes, observing them through economic models as a simplified version of an economy.

The most significant and distinguished changes in the economic structure that one encounters in the literature are the following:

1. Changes (increase) of the accumulation rates (Rostow, Lewis),

2. Changes of the sector composition of the economic activities, initially focused on the allocation of the employment (Fisher, Clark), and later on production and application of the factors (Kuznets, Chenery),

3. Changes in the location of economic activities,

4. Other aspects of changes of economic structure (demographic, distribution of income, etc.) (Syrquin, 1988).

Interrelated processes of structural changes which follow or are followed by economic development, we call structural transformation. The essence of structural transformation is the accumulation of physical and human capital, but also the changes in composition of demand, production, employment and trade. „The central phenomenon of what we call the structural transformation, are wide-economic occurrences, such as: industrialization, transformation of agriculture, migrations and urbanization. All these processes include a reciprocal interaction between the increasing income and the change in proportion of the supply and demand, and they are affected by macroeconomic and sector policies" (Chenery, 1988, pg. 205). Structural transformation causes some peripheral consequences of which we'll underline different socialeconomic processes. 
Beside such narrow interpretation of structural changes and structural transformation, there also exist broader interpretations considering institutional changes as well (North).

An evident reason for dealing with structural changes is for them being at the focus of development economy and modern economic growth. Without structural changes one cannot explain the process of growth, nor can a proper and comprehensive theory of economic development be evolved. At the focus of this problem is in fact a hypothesis that structural changes and economic growth are strongly interrelated. Economists, mostly, recognize this interrelation, and clearly emphasize the necessity of structural changes for further economic growth. For Kuznets, certain structural changes, not only in the economy, but also in social institutions, are necessary for modern economic growth. Chenery observes economic growth as a set of mutually related changes in the economic structure, necessary for its continual growth (Syrquin, 1988). Structural changes are very frequently put into context of labour productivity and technical progress, which are the main starter of the economic growth of the new age. The relationship between the economic structure and the increase of the productivity of a country, is the important fact which has drawn attention during the last decades. The idea that economic structure and its changes affect growth is old as the economy itself. Thus, a flexible structure of production is an important element of the high productivity rate, which enables the economy to redistribute resources quickly, in order to make the most of the change of the technical progress scheme (Fagerberg, 2000).

However, structural changes are not only analyzed to explain economic growth and development theoretically, but also to perceive their practical significance. Besides, all the theories are conceived in order to practically sustain the development, creating different types of economic policies. In this respect, we will explain the importance of structural changes and their impact on creating different development policies. Structural changes, thus, strongly affect the future creation of economic policy as a conscious influence of the state on the realization of certain goals of development. Economic policy can also affect (positively or negatively) the changes in the economic structure, bringing it closer or moving it away from its „optimum“.

\section{Structural Changes in Economic History}

The most general use of the term „structure“ in the development economy and economic history, implies to the relative significance of a sector in the economy in the terms of production and the use of the factors of production. This is why the industrialization was considered to be the central process of structural changes. However, in the recent history there occurs a process that can be called-tertiarization, which still marks the modern structural changes. 
Economic history and development economy differ exactly in the terms related to structural changes, but also in the approach to study of the very structural changes themselves. Development economy considers structural changes from a broad perspective, as an economic phenomenon in a broader sense, closely related to the aggregate growth.

Unlike this approach, economic historians view structural changes from a much narrow aspect, because they try to concentrate on specific phenomena and partial changes of the economic structure. Although these partial changes are very important elements of the entire entity that we call an economic structure, they are analyzed as isolated phenomena, and by doing so, simplify the analysis of structural changes. It is still a great paradox that historians neglected structural changes as a historical phenomenon, and they usually ignored the role of those changes in the economic development. Their main analysis of the economic growth is reduced to a belief that the industrial sector is of primary importance, and with this claim all other factors are almost completely neglected. In these analyses there's almost no mention about structural changes as a source of increased productivity in certain sectors.

One of the most significant historical approaches considering structural changes and structural transformation is the so-called "stages approach" presented by Rostow. This ,stage approach“ differs, as its name suggests, a few stages of economic development, of which the central stage is the ,take off stage" characterized by two elements. The first is the accelerated growth of the capital accumulation (almost doubled at this stage), and the second is the socalled „leading sector“ with its transformation of the production structure. Such approach was later criticized due to evident flaws, although these stages are widely used in the present-day economic analyses. The main critiques of this approach are directed towards the fact that he distinguished a unique path of development (abstracting the endogenous mechanisms of transition between the stages), and he also omitted the necessary preconditions for the take off stage.

Aside from ,the necessary premises for the take off“, discussed by Gerschenkron, he also emphasized that the process of industrialization in the European countries was abundant with specificities depending on a concrete economy. However, each country starts the process of industrialization, depending on the level of backwardness, but still varies from country to country. The character of industrialization we depend exactly from the initial level of backwardness of the country. Now, the analysis is not reduced to seeking a set of premises for initiating the take off stage (i.e. industrialization), but to discovering concrete methods of transition in which premises vary from case to case. The possibilities for different approaches of certain goals are central in mentioning different types of development. Gerschenkron even points out that the less developed country, the greater share of specific institutional factors, as banks or 
the state, which at the very beginning of industrialization have an impact on the increase of the offer of capital in the emerging industries (Syrquin, 1988).

Discussing ,the leading sector" as a key element of the take off stage, it should be mentioned that it transmits growth due to its connection to other segments in the economy. The term "leading sector", established and determined by Hirschman, is the essence of the so-called "staples approach“. Here, growth and structural changes are interpreted in the terms of the production characteristics of dominant natural resources (the staple), exploited for the foreign market. The literature studying this theory directs towards numerous examples of rapid growth based on accelerated exploitation of natural resources, but still, it will bring to continuous development without the simultaneous process of structural transformation, not only in the economy, but also in social and institutional fields. ${ }^{1}$

"The staples approach" is also closely related to the international demand, so that produced surplus for export affects the economic growth.

\section{Structural Changes in Development Economy}

Development economics evolved through an interaction between theoretical researches and empirical studies. Some of the basic theoretical approaches led directly towards the models of which some were the subjects of econometric tests and improvements, while others, due to their abstraction, became inadequate for further quantitative analysis.

Development economics is explained as dealing with different issues of structure and growth in less developed (developing) countries (Syrquin, 1988). The analysis of economic structure appears in development economy, mostly in two forms, or through two approaches: micro and macroeconomic.

The microeconomic approach studies economy, its market, institutions, mechanisms of resource allocation, creation and income distribution. Such approach is strongly related to the economic theory with little accent on economic history or long-term processes of change of economic structure.

The macroeconomic approach, however, perceives economic development as a set of interdependent long-term processes of structural transformation which follow the growth. The main characteristics of this approach are: broader economic phenomena, such as: industrialization, urbanization, agricultural transformation, what Kuznets simply called „modern economic growth“. This is the essential comparative approach which draws the facts and information from the historical evolution of developed (progressive) economies and relationships among structural processes and growth between countries.

\footnotetext{
${ }^{1}$ So-called examples of growth without development.
} 
The earliest researches of development economics, point out aggregate demand as a central category. The importance of demand in development economics was especially emphasized in Keynesian economic theory, due to which it is called the economy of demand. Such development economics of the 1950s recognizes two key components of structural transformation- accumulation and sector composition. Both of them affect economic politics: the first one affects its aggregate level, and the second - certain disaggregate levels.

Thus, it can be concluded that accelerated sustainable growth implies the increase in accumulation rate, but also a sustainable balance between different sectors in order to prevent disbalances at the markets of goods or factors.

Approximately, at the same time, emerges a neoclassical interpretation of economic growth which supports a different view, and unlike the structural emphasis of aggregate demand, this interpretation focuses on aggregate offering. Long-term growth, according to neoclassicists, is entirely independent from the savings (accumulation) rate, and intersector disbalance is intolerable.

Earlier researches and studies of economic structure discuss about harmonic changes in resource allocation depending on the income growth. A significant contribution, in that sense, makes Engel's Law of demand and the universal reallocation of labour from agriculture to industry, an later from industry to service/tertiary sectors.

Postwar analyses of demand, production and the usage of factors stand out again in studying economic structure. Kuznets wrote that studies of long-term growth bear essential advantage measuring structural transformation as a whole, and not dealing separately with each its component. Such synthetical analysis of structural transformation as a whole, enabled noticing simple schemes of the increase of demand, production, trade and employment. Although Kuznet's results turned out to be ,rugged“ in the modern econometric analysis, it still stimulated wider research of the unique phenomena of development, which he calls ,stylized facts“.

Development economics studies the methods of different sectors' adaptation to changes in demand, offer of factors and technology over time. Its analytical apparatus consists of models that can „catch" the differences between the sectors important for a concrete issue in question, but it also consists of various empirical studies that practically support theoretical views and anticipations.

Unlike the neoclassical approach which makes a simple distinction of the economy to sectors producing tradable goods (with a high substitution), and sectors producing non-tradable goods, development economics shows interest for studying structural adjustments in a more complex sense. Unlike other branches of economy, development economics has no adopted universal doctrine or paradigm. Instead, it has a constant evolution of thoughts that 
creates the basis for understanding the processes of modern economic development. Thus, for example, development economics distinguishes four principal approaches to economic development, of which the first three belong to the classical approaches group of development economics (Todaro, 2003). The first, also called linear stages of growth model, of which we specially point out the models of Rostow and Harrod-Domar, underline the crucial role of savings and investments in creating sustainable long-term growth.

In the second approach, structuralist in its essence, we encounter in structural change models. Lewis' simple two-sector model underlines the importance of analysis of numerous relationships between the traditional agriculture and modern industry, and Chenrey's empirical research is an attempt of precise recording of structural changes in economies under the conditions of numerous parameters actively participating in that process.

The theory of international dependency is an important approach of classical paradigm which implies that the structure and the world economy are crucial for the operation of concrete national economies and that the decisions of the developed countries, indeed, can affect the life of millions of people in the developing world.

The fourth approach is the so-called neoclassical approach, that primarily underlines the importance of the promotion of the efficient production and distribution through an adequate system of prices. Free market and open economy are necessary conditions for faster economic growth. it is also underlined the inefficiency of state-owned enterprises and planned economy which inhibit the economic growth.

All these approaches have both advantages and disadvantages, but the fact is that they deal with the phenomenon of economic growth, and whether we want to admit it or not, we still can consider them complimentary. ${ }^{2}$

This paper will deal with the structuralist perception of economic growth, i.e. with the influence of structural dynamics on economic growth and development, and vice versa.

\section{Empirical Research of Structural Transformation}

The program of empirical research on structural transformation originates from Kuznets, and the two main components are based on the long-term observation and the comparative framework. In his research, he remarked that comparative

\footnotetext{
2 The classical approach focuses on the demand, and the neoclassical on the offer, as the two inseparable components in economic analysis; savings and ivestments are indeed a very important factor of growth; economic structure and its dynamics affect the growth, but without the proper system of prices, free market, an open economy, in modern conditions-it is impossible, regardless of the strong influence of the devloped part of the world, which, again, cannot be abstract.
} 
experiences of certain national economies vary depending on their size, geographical location, and historical heritage, but they are crucial for spotting common characteristics and models.

In studying modern economic growth, Kuznets underlines the importance of three factor groups: transnational (potentially common for the entire world), national (observed via internal structure and the model of growth of individual nations), and international (appearing in studying interactions between different national units) (Kuznets, 1959).

Almost the same idea appears in Chenery's, who points out the universal and particular factors of economic growth. The most important universal factors are: common technological knowledge, similar human needs, approach to same markets of export and import, accumulation of capital conditioned by the increase in income and knowledge (skills) according to the increase in income (Chenery, 1960). The existence of transnational (universal) factors is the base due to which a harmony in the process of growth can be expected, as well as some common rules. National (particular) factors imply the inevitability of certain differences. The existence of transnational factors is the main excuse for the expected uniformity among the countries in the long-term transformation model, but such comparative analysis does not imply that there is a unique direction towards which all the economies tend to (Syrquin, 1988).

For the empirical regularities that follow the development they use the term „stylized facts", which likely came from Kaldor. It can be applied to a set of notions which Kuznets studied in order to explain a modern economic growth. One must admit that „stylized facts“ are much moderate term than ,the laws of history" mentioned by Engel, Hoffmann, Sombart and Wagner, but also more comprehensive, because it directs towards wider system phenomena. These "facts" are the empirical regularities observed in a sufficient number of cases, and the authors published numerous lists of basic „stylized facts“. Some of the facts are so obvious that they occur with every author, and some remain even today, because they are universally applicable. The other, however, is only a characteristic of a certain epoch and they cannot be applied in modern conditions.

The evident fact when we observe „the modern economic growth“, i.e. the growth after World War II are high rates of growth of GDP and GDP per capita, considerably higher than in the previous period. Rapid growth in the developed industrial economies (with high income), and also in the economies with average income after World War II, to the early 1970s, is partly the consequence of disturbing the main contours of the world production and trade and creating new ones. From the comparative analyses of the time it can be concluded that the countries with an average level of income grow faster than the countries with a higher or lower level of income. It can also be noticed that 
it came to a crucial geographic redistribution of the world production. ${ }^{3}$ Such kind of situation completely demanded the conclusions of the research from the 1930s, which supported the idea that the spreading of technological advantages among the countries during the process of industrialization would reduce the differences in their relative expences, and thus eliminate the ground for foreign trade. On the contrary, the foreign trade of industrial products after World War II increased enormously, mostly in the form of intra-industrial trade between the industrial countries, but also through the significant participation of many partly-industrial economies.

The process of economic growth can be defined as the result of expansion in production, resources and the increase of efficiency of their use. During the growth, the increase in input ( $\mathrm{L}$ and $\mathrm{K}$ ) accelerates, and the greatest contribution to growth in developed countries comes from the total factor productivity. The studies dealing with the increase of productivity in developing countries, show that productivity factors contribute to growth much more than productivity in the developed economies, partly due to the fact that the share of the added value of labour is much greater in rich than in poor countries.

The role of accumulation is immense, mostly because it bears the technological changes, and it is also a necessary factor for the intersector change of resources. Thus, a high rate of investments is desirable in order to sustain the aggregate demand and to decrease the unutilized capacities in the economy.

A high contribution of productivity growth to the increase of GDP is a relatively new phenomenon, and in the most of the countries the productivity of factors is higher than the rate of growth of GDP. At the sector level, a faster growth of the total factor productivity in the industrial than in the agricultural sector is recorded, although the growth is present in all sectors.

\section{Changes in Sector Proportions}

The change in sector composition is the most significant phenomenon of structural transformation. The increase in the social product is closely related to growth and changes in aggregate demand, trade and factors' use, and in turn they are related to the availability of natural resources and economic policy.

Such complex interconnection in fact determines the very structural transformation of one economy. The development of in-out approach stimulates the analysis of individual aspects of transformation within the multisector framework, and the basis of quantitative analysis dealing with structural transformation are the equations:

\footnotetext{
${ }^{3}$ In the period between 1950-1873. developed countries record a decrease in the share of production from $72 \%$ to $56 \%$, while "transitional" economies record an increase of share to more than $50 \%$.
} 
$\mathrm{Y}=(\mathrm{C}+\mathrm{I}+\mathrm{G})+(\mathrm{E}-\mathrm{M})=\mathrm{D}+\mathrm{T}$.

where the following symbols stand for: $\mathrm{Y}$ - gross domestic product, $\mathrm{C}$ - private consumption, I - investment consumption, $\mathrm{G}$ - consumption of the state, $\mathrm{E}$ export, $\mathrm{M}$ - import, $\mathrm{D}$ - domestic final demand, $\mathrm{T}$ - net trade.

At the sector level, the equation of material balance is of great importance:

$\mathrm{Xi}=\mathrm{Wi}+\mathrm{Di}+\mathrm{Ti}$

where: Xi - stands for gross output of sector i, Wi - for intermediary demand for the output of sector i, Di - for domestic final demand for the output of sector i, $\mathrm{Ti}$ - for net trade output of sector i. ${ }^{4}$

From the equation, it can be concluded that the demand is the key detail. The most general change in demand, affecting the very change of economic structure is the decrease of the food share in consumption (and the demand for it, simultaneously), and the increase of the investment demand share. In fact, what happens is the rehabilitation of Engel's law, confirmed by the postwar time and intersector series - with the increase of income in the process of structural transition, also increases the share of demand for non-food products, i.e. industrial products and services. An especially interesting thing is the fact that intermediary demand is the enormous size in the equation above, and that in the most of the countries it exceeds the percentage of $40 \%$ of the total gross output.

So, with the development also increases the consumption of intermediary goods, and their composition varies in the way that the relative use of intermediary primary products during the economic development slowly decreases, and industries and services increase. This state reflects the evolution towards a much complex system which demands the increase of the level of "fabrication", and technical changes and the increase in the relative price of labour causes the improved structure of production and the more intense use of input outside of the concrete sector. Dependency between industrial growth and modern services becomes increasingly larger.

In a closed economy the structure of production equals the structure of demand. However, in modern conditions we cannot discuss modern economy and not to at least little communicate with external (international) surroundings, and then we must include in the analysis both the level and structure of foreign trade. The share of trade in income is highly dependent from the size of national economy being analyzed, and the relations are the following: a small country has a relatively high share of foreign trade (and a capital from outside) in GDP, because a domestic market is relatively small, and the production structure

${ }^{4} \mathrm{Xj}=\mathrm{Uj}+\mathrm{Vj} ; \mathrm{Vj}=\mathrm{vj} \mathrm{Xj} ; \mathrm{V}=\Sigma \mathrm{Vj}=\mathrm{Y}$, Where $: \mathrm{Uj}$-stands for intermediary income of sector $\mathrm{j}, \mathrm{Vj}$-for added value in sector $\mathrm{j}$, vj-for added value ratio of sector $\mathrm{j}$. 
tends towards the increased specialization; among big countries, the situation is vice versa. The composition of trade and the type of specialization are determined according to availability of natural resources, traditional factor proportions and economic policy.

\section{Graph 1a Export of Primary Products}

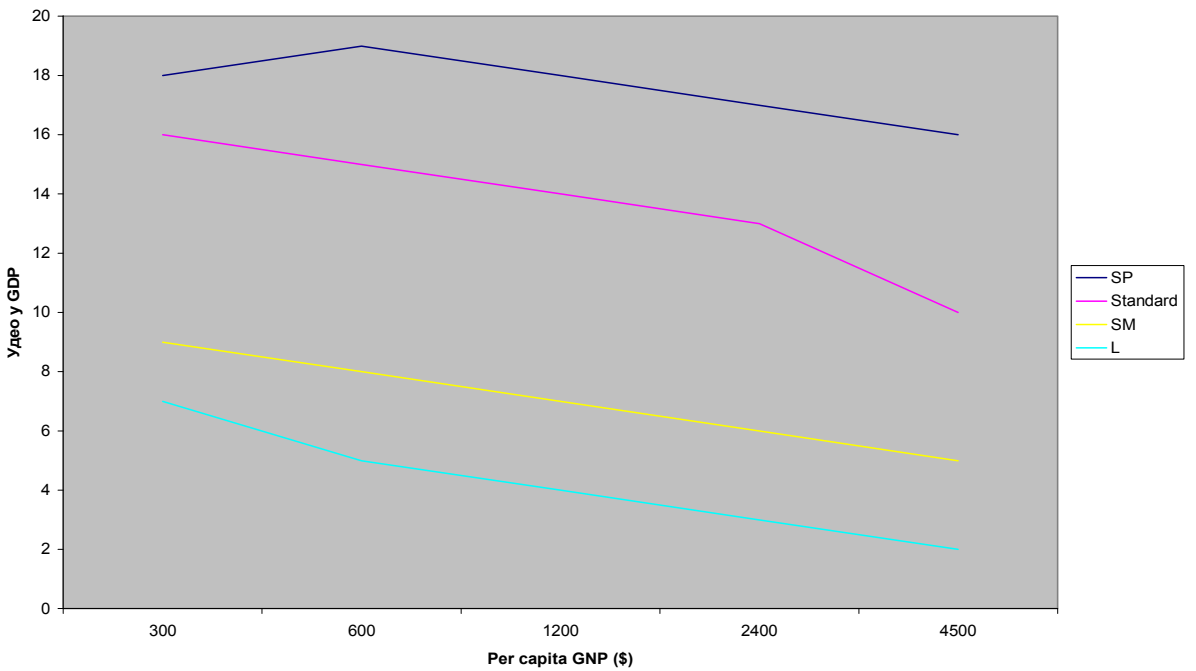

Graph 1b Export of Industrial Products

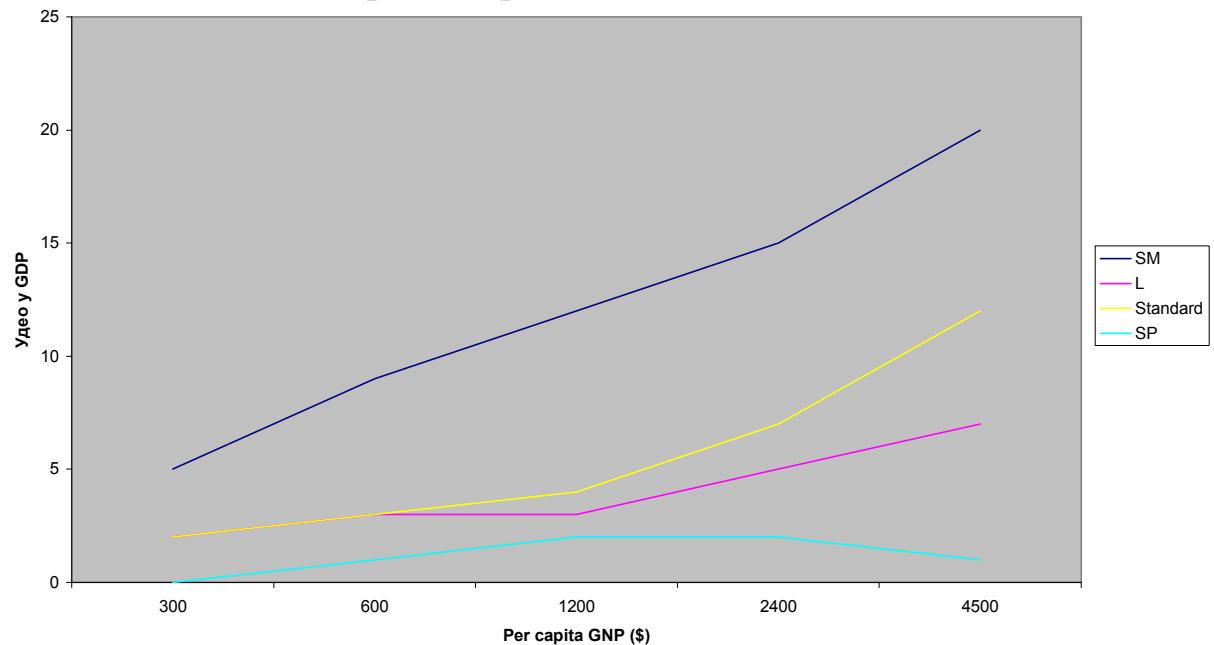

Source: M. Syrquin, "Patterns of Structural Change", Handbook of Development Economics, vol. I, Elsevier, 1988, pg. 234.

So, either we discuss about a big or a small country, it is important that its comparative advantages in cooperation with the economic policy, should bring 
it to such model of export whose structure moves from the export of primary to export of secondary products and services. Naturally, reorientation of export will not be of the same speed among the countries. Again, it would be faster in smaller countries, which due to insufficiency of natural resources to develop industrial production (and export of industrial products) in much earlier stages of development, unlike big countries, whose abundant quantity of resources allows little time delay in reorientation of export.

From Chenery's and Syrquin's analysis from 1986, it can be concluded that all the countries are divided in four groups ${ }^{5}$, as well as movement and structure of their export during development and structural transformation. Within small industrial countries, the export of industrial products soon exceeds the export of primary products, at the very beginning of the transitional period, which is not the case with small countries oriented towards the export of primary products, as well as among the big countries.

When a country starts with the export of industrial products, in the beginning they originate from the light industry sector, and much later it starts with the export of the products from the heavy industry sector, especially among small countries poor in resources.

Changes in commodity composition of external trade highy accelerates the changes in final and intermediary demand from primary to industrial products and services. Such changes are crucial in transformation, and they have been demonstrated on the long-term experience of almost all industrial countries after World War II. ${ }^{6}$

It goes without saying that the changes of foreign trade structure, i.e. of foreign and domestic demand will affect the change of the production structure, and therefore the employment trends in particular sectors.

The change in the commodity composition of trade accelerates changes in final and intermediary demand (from primary to industrial products and services). Such change is crucial in the transformation and it has been demonstrated on the long-term experience of almost all industrial countries after World War II.

\footnotetext{
${ }^{5} \mathrm{SM}$ - Small manufacturing oriented; L - Large; Standard; SP - Small primary oriented

${ }^{6}$ This share is measured through the following equation: $\frac{V_{i}}{V}=v_{i}\left(\frac{W_{i}}{V}+\frac{D_{i}}{V}+\frac{T_{i}}{V}\right)$
} 


\section{Graph 2a Share of Sector in the Added Value}

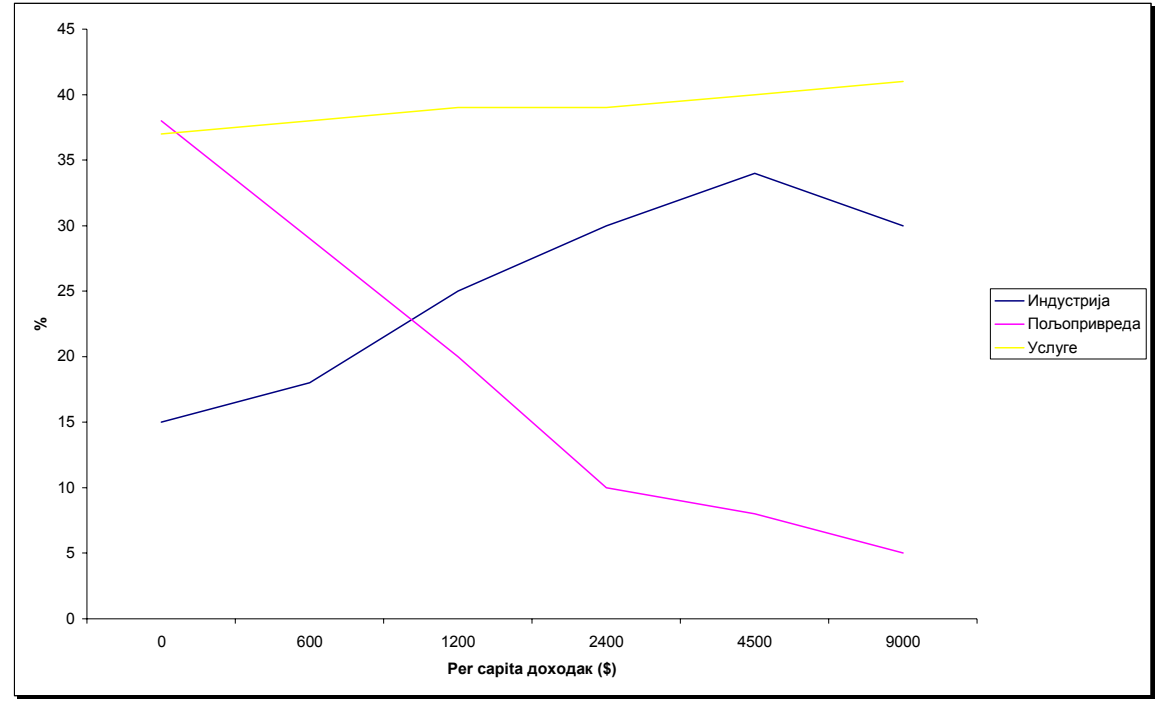

Graph 2b Share of Sector in Employment

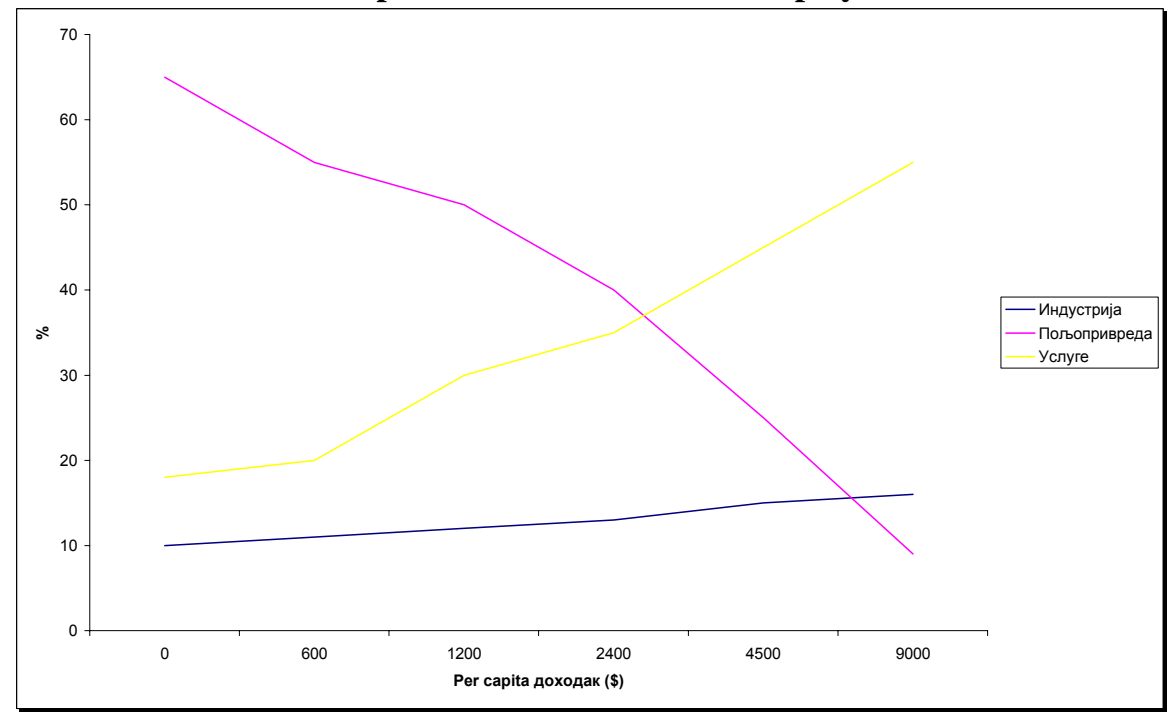

Source: M. Syrquin, „Patterns of Structural Change“, Handbook of Development Economics, vol. I, Elsevier, 1988, pg. 238.

If we should point out certain legalities from the anaylses of the second half of the last century, then the most significant would be the following: 
1. There is a certain shift of sector share in the added value, from the primary production to industrial and services;

2. The change of domestic demand affects, somewhat less than a half, the structural changes in one national economy, and net trade with approximately $10 \%$;

3. A relative use of intermediary primary sector input decreases;

4. There is a clear gap between the dynamics of employment trend from agriculture (to other sectors) and productivity growth "lagging behind" in that sector;

5. The increase of employment in industry is lesser than its decrease in agriculture, so the employment trend logically shifts from agriculture to the service sector;

6. The ratio of income and the share of agriculture in income and employment is inverse;

7. The growth rate of industrial production is positive, but it decreases with the income growth, so in almost all industrial countries we record a kind of deindustrialization over time;

8. The decrease of employment share of agriculture is followed by the decrease in its added value, but with a certain delay, because the initially greater share in employment exceeding the share in the total production makes the productivity labour in agriculture-decrease;

9. In almost all cases, the prices of agricultural and industrial products decrease over time;

10. During the process of industrialization, the industrial sector composition constantly and significantly changes, i.e. with the increase of income, production shifts from light to heavy industry.

\section{Modern Economic Growth and Structural Changes}

When we observe economic growth over time, and the related structural transformation, the situation has not considerably changed - a few decades ago, as today, economic growth requires structural changes. The only difference between the traditional and new development economics is in the approach. Nowadays, it is necessary to observe both differences and specificities of development - of developed (progressive) and developing economies, because that the development gap between them has increased over time and it must not be overlooked. The main differences in the nature of growth between the developed and developing countries are also a topic of significant discussions among the economists. New trends shift from the traditional perspective (distinguishing the accumulation of capital as crucial for economic development), thus pointing out some new determinants of modern development, such as: productivity, human capital, innovations, economic policy. 
The increase of productivity in developed countries, mostly relies on technical innovations, being the only factor of growth for them. For developing countries, growth and development are less dependent than „pushing the technological limits“, and more dependent than „directing production towards activities with a higher level of productivity" (UN Economic and Social Affairs, 2006).

Such structural changes among the undeveloped countries are mostly attained through adoption and the adaptation of existing technologies, import substitution and faster admittance to the world market, and faster accumulation of physical and human capital. Only little number of developing countries were able to create an optimum $\mathrm{R} \& \mathrm{D}$, and thus a team and technological innovations, even today highly concentrated in the developed world.

In modern conditions, ,the new theories of growth" recognize the mentioned differences, and the role of external economy becomes important in forming physical and human capital and technological innovations. These theories, also, actively relate dynamic economics of scale to learning by doing and institutional factors.

The economists who follow the tradition of classical economic development, support the idea that the growth in developing countries, is in fact related to structural changes, that can also be called - industrialization, i.e. movement towards highly industrialized sectors that will contribute to economic development dynamically. Because of the greater increase in productivity in these sectors, coming from the greater economies of scale, innovations and learning by doing. The unemployed labour force from the rural sector, but also the informal urban sector enables an elastic offer of labour, allowing this process of transformation to flow without the considerable limitations (possible to occur on the side of offer for labour force).

Although previous empirical studies showed the importance of industrial development for the long-term economic growth, modernization of agriculture is also crucial for the dynamic transformation (and growth).

The way the economies climb the ladder of economic development, the same way the service sector takes up the more important position. Modern service sector is also the source of productivity, but very significant in supporting the industrialization itself. Besides, the international trade via services offers a new possibility for development of export.

Kaldor claimed that productivity and growth mutually accelerate one another. However, the influence of the increase in productivity on economic growth had been more studied than the inversed influence-the influence of economic growth on the increased productivity. 
Taking into consideration modern economic conditions, i.e. the situation when in most of the countries (especially undeveloped) resources are not fully exploited, not only that the faster growth will lead to better exploitation of resources, but the increase of productivity (related to economic growth) will accelerate the resources to shift from the sector with low, to sectors with high productivity.

However, the low economic growth will lead to the increased unusage of resources and negative effects on productivity. In addition, the link between the low economic growth and the low increase of productivity has no base of its own due to a lack of technical changes, but due to growing unusage of resources. If the resources are not exploited, low productivity will rather be an effect and not a cause of low economic growth.

Dynamic structural changes, in modern conditions, are more than the mere growth of industry, and the related services. Above all, they imply a constant generating of new activities and their capacity to absorb the surplus of labour. Strengthening of integration ties between the old and new sectors, and fast integration of new sectors into domestic market are of enormous importance, which distinguishes economic policy as an important actor in this process.

The level of integration of domestic economy affects the size of the domestic market, but also the potentials for export and the possible benefits from the foriegn trade and the inflow of FDI. Only when the strong „domestic ties" are created, the integration into the world market can create a technological progress and contribute to a sustainable economic growth.

\section{Economic Structure an Innovations}

The dynamics of production structure in cooperation with the favourable macroeconomic environment, is one of the most significant determinants of modern economic growth. A capability of constant generation of new dynamic activities is the essence of the developing process. It could be said that the growth, in fact, presents the combination of macro and microeconomic dynamics.

The dynamic change of economic structure affects the sector composition of production, intra and inter-sector relationships, market structure, operation on factor market and the institution. Structural dynamics could be observed as a part of macroeconomic dynamics, i.e. as one of the most important parts of it. Together with other factors positively affecting the macroeconomic dynamics (institutions and human capital), it can bring to a stable growth. Investment performances and the current account balance, are mostly the result of structural dynamics. 
The dynamics of production structure can be imagined as an interaction of four main forces: innovations, complementarity, dynamic economy of scale and elastic offer of factors. (Ocampo, 2002).

In a dynamic and changeable world, innovations are a condition for an enterprise or a sector to develop. Without innovations, sectors or enterprises tend to disappear. Accordingly, an innovation implies „creation“ of production activities, an enterprise or a sector or „destruction“" of the existing ones.

In undeveloped countries, innovations have an influence on the development of new activities as a result of the technological revolution and the increasing demand for particular services. Innovations also affect the increase of export orientation of an enterprise having served for import substitution.

Unfortunately, on the other hand, innovations also cause the destruction of the existing production activities and capacities, and elimination of some basic characteristics, which is the result of changes in extreme conditions (,,creative destruction"). Of course, creative forces must prevail if the goal is growth.

With innovations and structural changes caused by them, it is also closely related to the issue of investments, therefore, capital innovations and great structural changes require capital investments.

The existence of the network of various bidders of goods and services, marketing channels, and different regulatory institutions, enabling coordination by spreading information among economic subjects, demands complementarity. Due to mutual complementing of private and public institutions, as well as different parts of of economic structure, growth would not be possible.

Dynamic economics of scale is closely related to innovations, so as it is getting more mature, it increases the dynamic economics of scale. An innovation must go through the stage of studying and maturing (evolutionary theories of technical changes) also including the accumulation of ,intangible“ human and organizational capital. It would be the best if the innovations are the direct result of production experience, but since technology is unevenly available, and it is differently used by a different enterprise or country, then it seems not to be the case every time. Macroeconomic base of economy of scale is the exact link between productivity and accumulated production experience embodied in an innovation. The pressure of competitiveness guarantees that the innovations will be copied and spreaded.

The process of spreading of innovations highly depends on elasticity of factor offer, i.e. the ability to attract capital, labour and natural resources. From the elasticity of offer of particular factors will depend the direction and character of innovations, and ultimately - productivity and growth. 
What would the undeveloped countries set off from the point of undevelopment, are the the so-called „deep“ innovations, the result of production experience and domestic R\&D. Only the combination of deep innovations with dynamic economics of scale and a strong comlementarity can bring to „creative restructuring" and the increase in apsorbtion of labour in dynamic activities with a great productivity. If, however, the innovations are copied or imitated, and as such be ,superficial“", as happens among the most of developing countries, it can bring to the situation when the destructive forces start prevailing. They would be increasing and accelerating the opposite (undesirable) effects, leading towards the increased structural heterogeneity, and the surplus of labour will find its refuge in the less productive activities. Then the negative effects will be repeated, the investments will decrease, as well as the savings, technological lag will increase, institutions will get weak, the dynamics of restructuring will get low, and ultimately the growth will slow down.

\section{Conclusion}

In the following lines the author discusses some facts related to modern economic growth, drawn from intersector, time and historical analyses, and also from the new debates on economic growth.

The obvious fact is that there are huge inequalities in the world economy, when the development is in question. These inequalities have been spotted early in the history of modern capitalism, and this gap in development over time has considerably increased, which means that the convergency in per capita national income is a true rarity, despite some theoretical claims that it will become a rule. This is why development is not the matter of ,going through a phase" according to a universal model that all the countries should go through, which the developed countries have already gone through. Here the author discusses the increase in income per capita in the conditions of limitations forced by the position in the world hierarchy and the internal structure of developing countries.

The growth is rather uneven then even. It comes in streams, suddenly, and that is the basic lesson of economic growth's historical analyses. Structuralist economy views growth as a very dynamic process in which sectors and enterprises mutually confront, so as a result there occurs a decline or disappearance of some enterprises and sectors, and on the other hand, the emergence of the new ones. Hence, that would be a constant change in production structure and the repetition of „creative destruction“ phenomenon. If we observe ,the balloon effect", then the structural changes are the product of growth and they do not have the power to be explained as the rate of growth "pushing up". However, observing ,the effect of structural dynamics“, it is evident that the solution of accelerated growth lies in the structural changes. 
The ability of a constant generation of new dynamic activities (innovative activities), is the essence of the process of growth. Of course, structural transformation is not automatic and without expenses, and the disability of creating new economic activities can lock the process of development.

Another fact, without which is impossible to study modern economic growth is the elasticity of the offer of factors. It goes without saying that for a dynamic economic growth it is necessary to have the attraction of the production factor-capital, and especially labour force. The mobility of the labour force (especially highly qualified) is very important for the process of growth, i.e. creating of innovations that would affect the growth. The mobility of capital and labour is more important for the developing countries, because due to their ability to attract factors the level of their innovation as an engine of future growth will depend on them.

If we would like to point out some other development laws from the analyses of the second half of the last century, it would be the following.

There is a considerable shift of sectors in the added value from the primary production to industrial production and services, and at the same time a relative use of intermediary primary sector input.

Furthermore, there is a clear gap between the dynamics of employment trend from agriculture (towards other sectors), and productivity growth which is lagging behind in that sector. The increase of employment in industry is less than its decrease in agriculture, so it's logical that employment from agriculture goes forward to service sector. The decrease of employment share in agriculture follows the decrease in its added value, but with a certain delay, because the initially greater share in employment exceeding the share in the total production implies that the productivity of labour in agriculture declines.

The rate of growth of industrial production is positive, but it declines with the growth of income, so in almost all industrial countries there is recorded a kind of deindustrialization over time, and in almost all cases the prices of agricultural and industrial products decline over time.

\section{References}

Chenery, H. (1988) "Introduction”, Handbook of Development Economics I: 205-210.

Chenery, H. B. (1960) „Patterns of Industrial Growth“, The American Economic Review, 50 (4): 626-632.

Doyle, E. (1997) „Structural Change in Ireland“, Journal of Economic Studies, 24: 58 68. 
Fagerberg, J. (2000) "Technological Progress, Structural Change and Productivity Growth: A Comparative Study", Structural Change and Economic Dynamics, 11: 393-418.

Korošić, M. (1976) Cijene i strukturne promjene u privredi, Zagreb: Informator.

Kuznets S. (1959) On Comparative Study of Economic Structure and Growth of Nations, New York: NBER.

Ocampo, J. A. (2002) Structural Dynamics and Economic Development, Social Institutions and Economic Development, Netherlands: Kluwer Academic Publishers.

Syrquin, M. (1988) „Patterns of Structural Change“, Handbook of Development Economics I: 218-220.

Todaro, M., Smith, S. (2003) Economic Development, New York: Addison Wesley.

UN Economic and Social Affairs (2006) „World Economic and Siocal Survey 2006, Diverging Growth and Development", NewYork: UN.

\title{
STRUKTURNE PROMENE I STRUKTURNA TRANSFORMACIJA U SAVREMENOJ RAZVOJNOJ EKONOMIJI
}

\begin{abstract}
Apstrakt: Mnogo je različitih korišćenja koncepata strukture i strukturnih promena $\mathrm{u}$ ekonomiji. Najgrublja distinkcija pristupa $\mathrm{u}$ vezi sa ovim pitanjima, jeste na pristup razvojne ekonomije i ekonometrijski pristup. U radu ce se koristiti pristup koga zastupa razvojna ekonomija, jer se čini da ekonometrijski pristup, isuviše pojednostavljuje analizu strukture i strukturnih promena. Razvojna ekonomija koja se razvijala kroz interakciju teorijskih istraživanja i empirijskih studija se karakteriše kao bavljenje različitim pitanjima strukture i rasta $u$ manje razvijenim (nerazvijenim) zemljama. Analiza privredne strukture se u razvojnoj ekonomiji uglavnom posmatra, kroz mikro- i makro pristup. U radu će se koristi makroekonomski pristup, koji privredni razvoj vidi kao set međuzavisnih dugoročnih procesa strukturne transformacije koji prate rast. Za razliku od neoklasičnog pristupa koji pravi jednostavnu distinkciju privrede na sektore koji proizvode dobra kojima se trguje (i koja su sa visokom supstitucijom) i sektore koji proizvode dobra kojima se ne može trgovati, razvojna ekonomija izučava strukturna prilagođavanja u mnogo kompleksnijem smislu. Za razliku od ostalih ogranaka ekonomije, razvojna ekonomija nema prihvaćenu univerzalnu doktrinu ili paradigmu. Umesto toga ona ima kontinuiranu evoluciju razmišljanja koja stvaraju osnovu za razumevanje procesa savremenog privrednog razvoja.
\end{abstract}

Ključne reči: privredna struktura, strukturne promene, strukturna transformacija, razvojna ekonomija, sektorske proporcije. 